\title{
Trzej polscy artyści $w$ Chinach w latach 50. XX wieku
}

Streszczenie. W latach 50. XX wieku delegacje artystów polskich do Chin stanowily ważny element międzynarodowej polityki kulturalnej nowo powstałego bloku wschodniego. W założeniu miały służyć ugruntowaniu ideologicznego podobieństwa sztuki w krajach socjalistycznych i wzmacnianiu więzi politycznych. W praktyce stanowiły często istotne przeżycie artystyczne i źródło ważnych inspiracji dla odbywających je twórców. Artykuł analizuje trzy przypadki artystów, których rysunki dokumentujące podobne podróże znajdują się obecnie w zbiorach Muzeum Azji i Pacyfiku w Warszawie i w których twórczości doświadczenie to zaznaczyło się w różny sposób. Dla Tadeusza Kulisiewicza podróż chińska była ważnym epizodem, do którego wracał jeszcze po wielu latach. Aleksandra Kobzdeja zainspirowała do fundamentalnej zmiany w jego twórczości, rozpoczynając proces, który od socrealizmu miał go doprowadzić do abstrakcji. W przypadku Andrzeja Strumiłły stanowiła początek znakomitej artystycznej drogi, którą w dużej części wytyczyła fascynacja kulturami i sztuką krajów Azji.

Słowa kluczowe: sztuka polska, polscy artyści w Chinach, socrealizm, polska sztuka współczesna, Chiny.

W

latach 50. XX wieku podróże polskich artystów do Chin stanowiły istotny element państwowej polityki kulturalnej. Wyjazdy te miały budować sieć oficjalnej wymiany, prezentować i propagować osiągnięcia dwóch krajów socjalistycznych, wzajemnie dla siebie egzotycznych, a jednak - dość niespodziewanie - sojuszniczych. Były pomyślane jako droga poszukiwania podobnych rozwiązań, stawały się jednak często czymś wręcz przeciwnym: doświadczeniem różnicy, spotkaniem z innością. Wyprawy takie organizowały wówczas i inne kraje bloku wschodniego, a niezależnie od ich politycznego, z góry określonego charakteru dla wszystkich bywały okazją do autentycznego kontaktu z dorobkiem chińskiej kultury, źródłem inspiracji artystycznej i kolekcjonerskiej ${ }^{1}$. 
Oficjalnym celem było umacnianie „przyjaźni między narodami” w drodze wymiany kulturalnej, której okres największego ożywienia przypada na lata 1951-1959². W 1951 roku podpisano międzypaństwową umowę o współpracy kulturalnej. Jej rezultaty to m.in. program stypendialny, umożliwiający polskim adeptom sinologii studia w Chinach, wydawanie w obu krajach licznych tłumaczeń literackich oraz liczne wystawy i tournée artystyczne na niespotykaną później skalę3. Już w 1951 roku w Muzeum Narodowym w Warszawie odbyły się dwie wystawy: „Nowe Chiny” oraz „Wystawa sztuki Chińskiej Republiki Ludowej”. W 1952 roku w Pekinie prezentowana była wystawa plakatu polskiego; kolejna, w połączeniu z ilustracją książkową, krążyła po Chinach w 1955 roku. W 1953 roku częścią polskiej prezentacji na targach w Pekinie była przekrojowa wystawa sztuki polskiej. W 1954 roku w Pekinie i Szanghaju pokazano polskie wycinanki, a w 1958 szeroki przegląd polskiej sztuki ludowej. Jak widać, obustronnie podkreślano zarówno rolę tradycji ludowych, jak i nowe, głównie socrealistyczne oblicze sztuki obu krajów. W obu kierunkach wyjeżdżały delegacje twórców kultury (do najważniejszych polskich wizyt w Chinach należały te z lat 1952, 1953 i 1954), nawiązywano kontakty na szczeblu ministerstw i stowarzyszeń twórczych. Nagłe zerwanie kontaktów po ogłoszeniu rewolucji kulturalnej w 1965 roku położyło kres tym intensywnym, choć mocno upolitycznionym działaniom.

Wśród uczestników tych podróży byli artyści plastycy, m.in. Jan Cybis, Jerzy Panek, Leon Michalski, Artur Nacht-Samborski, Jan Tarasin i Jan Zamoyski. Prace trzech z nich, bohaterów niniejszego artykułu, obecne są dziś w zbiorach Muzeum Azji i Pacyfiku w Warszawie. Są to: Tadeusz Kulisiewicz, Aleksander Kobzdej i Andrzej Strumiłło. Wszyscy trzej przywieźli z Chin liczne rysunki oraz bardzo różne inspiracje do dalszej pracy. Dla Kulisiewicza, najstarszego i dojrzałego już artysty, była to pierwsza podróż pozaeuropejska, ważna i interesująca, ale nie decydująca dla jego rozwoju. Dla Kobzdeja - punkt przełomowy, początek drogi, która miała go zaprowadzić daleko od socrealizmu, którego wyznawcą był przed wyprawą do Chin. Dla Strumiłły wreszcie to początek trwałej fascynacji kulturami Azji, towarzyszącej mu nieprzerwanie do dziś i wyjątkowej na polskiej scenie artystycznej.

\section{Kulisiewicz}

Tadeusz Kulisiewicz (1899-1988) to artysta, który - jak wiadomo - uczynił z rysunku niepowtarzalne narzędzie ekspresji. Zwykle rysunek jest tylko jedną z form artystycznego wyrazu; dla Kulisiewicza, zaczynającego od grafiki, rysunek stał się

\footnotetext{
2 Zarys historyczny polsko-chińskich kontaktów kulturalnych na podstawie: JACOBY 2009, s. 333-339; Hu GuANG Hua 2011; Li Chao 2011.

3 Intensywność polsko-chińskiej wymiany teatralnej i zainteresowanie teatrem chińskim w Polsce tego okresu obszernie udokumentował Zbigniew Osiński - OsıŃsKi 2008.
} 
głównym, niezależnym i wydoskonalonym medium. Po wojnie, w której zniszczeniu uległą znaczna część jego dorobku, Tadeusz Kulisiewicz powrócił jako wykładowca na warszawską Akademię Sztuk Pięknych i stał się aktywnym uczestnikiem oficjalnego życia kulturalnego. Podróż do Chin z grupą polskich artystów i działaczy (m.in. poetą Adamem Ważykiem, śpiewaczką Antoniną Kawecką, pianistą Zbigniewem Szymonowiczem) w 1952 roku była jego pierwszą wyprawą poza Europę, w której zarazem uczestniczył jako jedyny plastyk. Później odwiedził także Indie, Meksyk, Brazylię i Kubę.

W jego chińskim notatniku i szkicowniku zarazem ${ }^{4}$ znaleźć można ślady zaskoczenia i zadziwienia w kontakcie z obcą kulturą, ale przede wszystkim liczne szkice wykonane czarnym długopisem, zwykle opatrzone notatkami. Wiele lat później dokonywał ich transpozycji na bardziej „szlachetną” technikę tuszu w swojej pracowni, zawsze jednak - jak zauważał Wojciech Skrodzki ${ }^{5}$ - z tą samą siłą i żywotnością doświadczenia. Poza kartkami tego zeszytu powstały także niezależne rysunki z podróży. Irena Jakimowicz w katalogu do indyjskiej wystawy Kulisiewicza pisała później, że wyznacznikiem jego sztuki są „wewnętrzna równowaga i dojrzałość, pozwalające łączyć obserwację z uogólnieniem, współczesność z tradycją”. Słowa te można z powodzeniem odnieść również do jego rysunków chińskich.

Szkicownik artysty na początkowych stronach zawiera tylko zapiski dotyczące szczegółów podróży; szybko zaczynają przeważać rysunki, zwykle z krótkimi opisami, a często także z chińskimi nazwiskami lub nazwami zapisywanymi przez Chińczyków (wciąż jeszcze starymi znakami) i fonetycznie transkrybowanymi na polski. Niekiedy pojawiają się kopie dawnych napisów i objaśnienia dotyczące ewolucji pisma, które wyraźnie fascynowało rysownika, podobnie zresztą jak i chińska architektura.

Kulisiewicz szkicował więc w Pekinie widoki z Zakazanego Miasta czy parku Beihai, notując przy tym oficjalne objaśnienia zjawisk historycznych i społecznych przekazywane gościom. Wiele mówiono o zachodnich agresorach w przeszłości i teraźniejszości Chin. „Amerykanie zasłużyli na tę nazwę - kolonizatorów”, notował, po czym zapisywał, że obecnie „Europejczyk na ulicy Pekinu kojarzy się zupełnie inaczej: dobry człowiek, człowiek radziecki niosący wolność" - to przykłady konwencjonalnych i konformistycznych, jak się dziś wydaje, komentarzy, jakie przewijać się będą przez cały notatnik. Artysta obserwował, jak przeplata się stare i nowe: 3 października 1952 roku był zarazem Dniem Walki o Pokój i Świętem Jesiennej Pełni Księżyca, a entuzjastyczna, kształtująca socjalistyczną przyszłość kraju młodzież wypełniała historyczne budowle. Patrzył na żyjące miasto przez pryzmat

\footnotetext{
4 W zbiorach Fundacji Stypendia i Nagrody im. Tadeusza Kulisiewicza; kserokopia w Bibliotece Azjatyckiej Muzeum Azji i Pacyfiku w Warszawie.

SKRODZKI 1979.

6 JAKIMOWICZ 1976, s. 5.
} 
dawnej sztuki chińskiej, którą - jak możemy się domyślać - równolegle poznawał. Park Beihai był dla niego „jakby jakieś stare chińskie rysunki tuszem”.

Trasa podróży była urozmaicona, obejmowała odwiedzanie wsi i miast, zabytków przeszłości i ośrodków przemysłowych świadczących o nowoczesności i rozwoju Chin pod rządami partii komunistycznej. Jak to bywało z wieloma artystami, pomimo nacisku kładzionego na współczesność większe wrażenie robiły na Kulisiewiczu świadectwa historii. Widać to wyraźnie po dokumentacji pobytu w Hangzhou, wspaniałej stolicy Południa, wtedy jeszcze niezdewastowanej przez Rewolucję Kulturalną. Tu artysta pływa po słynnym z widoków Zachodnim Jeziorze (obowiązkowy punkt wycieczek do Hangzhou również dzisiaj), które nazywa „zaczarowanym", wspomina o Su Dongpo i innych poetach chińskich, czyni notatki o Laozi, starej religii chińskiej, bóstwach i świątyniach. O skalnych rzeźbach Latającego Szczytu mówi: „chyba największe przeżycie”. Ogląda spektakle teatralne o małpim królu Sun Wukongu i Motylich Kochankach, Liangzhu; już w Pekinie opera, choć niezrozumiała, wyraźnie go zainteresowała z estetycznego punktu widzenia. W Hangzhou zaplanowano też dla gości wizytę w Akademii Sztuk Pięknych i spotkania z artystami.

Z Kantonu przywozi Kulisiewicz wiele rysunków łodzi, wspomnienia barwnego, pulsującego życiem miasta, w którym jednak daje mu się we znaki upalna, pomimo jesieni, duszna pogoda, a także tropikalnych owoców. Szanghaj, zgodnie z popularnym stereotypem, kojarzy mu się z Paryżem, ale również zaciekawia ruchliwym portem. Tam też odbywają się kolejne spotkania z miejscowymi twórcami, polsko-chiński koncert, a także wykład o historii chińskiego malarstwa, którego konkluzją jest konieczność postępu i zerwania z tradycją.

W tym duchu przebiega też ponowny pobyt w Pekinie po powrocie z Południa (w trakcie 70-godzinnej podróży artysta szkicuje krajobrazy i obsługę pociągu). Polska delegacja 27 października uczestniczy na pekińskiej ASP w otwarciu wystawy współczesnego malarstwa i drzeworytów, realistycznych w formie i rewolucyjnych $\mathrm{w}$ treści. $\mathrm{Z}$ drugiej strony jednak następuje spotkanie z klasykiem malarstwa, Qi Baishi (krótki zapisek mówi: „Czi-Bai-Szi artysta stary 86 lat”), nadal nieodmiennie szanowanym za swoje interpretacje wielowiekowych motywów sztuki chińskiej, oraz kolejne wizyty w operze, postrzeganej wówczas jako cenny przejaw kultury narodowej.

Z Pekinu goście udali się na kolejną wycieczkę, tym razem do Mongolii Wewnętrznej, Datongu i Luoyangu, gdzie Kulisiewicza urzekły skalne świątynie. Groty Yungang w Datongu nazwał w swym dzienniku „chińskim Partenonem” - znamienne, powracające również w jego późniejszej podróży indyjskiej porównanie do dziedzictwa europejskiego. Kilka rzeźb stało się tematem szkiców.

Pojedyncze dzieło sztuki jest jednak w szkicowniku chińskim Tadeusza Kulisiewicza motywem dość rzadkim. Dwa podstawowe aspekty podróży: pejzaże i ludzie zajmują jego karty w zrównoważonych proporcjach; w późniejszych pracach studyj- 
nych skupiał się będzie raczej na portretach. Jego modele to częściowo osoby anonimowe lub znani dziś tylko z zapisanego przy rysunku nazwiska chłopi i robotnicy, nierzadko honorowani bohaterowie pracy, częściowo zaś ważne postacie ówczesnej kultury chińskiej, w tym najsłynniejszy aktor w dziejach opery pekińskiej Mei Lanfang i jego sceniczny partner Jiang Miaoxiang ${ }^{7}$, a także poeta Lu Yuan. Pejzaże często szkicowane były z okien pociągu podczas długich podróży, co wpłynie również na charakter ich późniejszych powtórzeń - rozległych panoram, widzianych z dystansu.

W latach 80. artysta wrócił do swoich starych szkicowników za namową założyciela i ówczesnego dyrektora Muzeum Azji i Pacyfiku, Andrzeja Wawrzyniaka, który następnie nabył do zbiorów znaczną część prac z serii chińskiej (1982) i indyjskiej (1983). Zostały one zaprezentowane na wystawie „Azja Mistrza Kulisa” w 1984 roku ${ }^{8}$. Motywy ze szkicowników powracają silnie uproszczone, syntetyczne i zarazem bardzo precyzyjne - Barbara Pokorska w 1993 roku porównała je do późnych prac Picassa i Matisse’a' ${ }^{9}$ Z pewnością polski artysta pozostaje w tym samym kręgu klasycyzującego modernizmu. Zostaje tylko czysta, czarna kreska na białym tle, czasami sprowadzona do absolutnego minimum formy. Szczególnie szlachetnego charakteru nabierają w tej późnej redakcji portrety, ograniczone do minimum linii o stężonej ekspresji - twarze ludzkie, których rysy zdradzają pochodzenie etniczne, ale z których emanuje przede wszystkim ponadkulturowe ogólnoludzkie doświadczenie. Ani w serii chińskiej, ani indyjskiej nie ma natomiast śladów wpływu sztuki tych krajów - styl Kulisiewicza jest zawsze jego własny, co również zauważała Barbara Pokorska ${ }^{10}$.

\section{Kobzdej"}

Aleksander Kobzdej (1920-1972) w chwili wyjazdu do Chin był już jednym z najważniejszych przedstawicieli polskiego socrealizmu, autorem ikonicznego obrazu Podaj cegłę, zaś w nieodległej przyszłości miał się przekształcić w jednego z czołowych twórców abstrakcji i malarstwa materii. Podróż chińska, według jego własnych opinii, znacznie się do tej przemiany przyczyniła.

W 1953 roku był artystą oficjalnie uznawanym i wyróżnianym, akceptującym założenia sztuki socrealistycznej w służbie nowego społeczeństwa. Został jednym z członków delegacji, która miała wziąć udział w otwarciu polskiej wystawy gospodarczej w Pekinie, obejmującej również obszerny dział artystyczny. Na jej czele stał Włodzimierz Sokorski, minister kultury i główny ideolog realizmu socjalistycznego

\footnotetext{
Za identyfikację tej postaci i transkrypcję dziękuję Maurycemu Gawarskiemu. 
w Polsce. Jego dziennik podróży, opublikowany krótko po powrocie, stanowi doskonały komentarz do rysunków Kobzdeja, z których 17 posłużyło jako ilustracje ${ }^{12}$. W delegacji znaleźli się również m.in. wybitni muzycy: Lidia Grychtołówna, Andrzej Hiolski, Edmund Statkiewicz oraz sinolog Witold Jabłoński.

Wybór tematów szkicowanych podczas chińskiej podróży Kobzdeja wydaje się zainspirowany zarówno przez polityczne założenia delegacji - pokazać nowe, ludowe Chiny rozwijającego się przemysłu i społecznego awansu, zarazem egzotycznie atrakcyjne, jak i przez osobiste zainteresowanie artysty całkowicie nowym i często niezrozumiałym otoczeniem. Bez wątpienia było to dla niego ważne i formacyjne doświadczenie. Późniejsi krytycy wskazują, że to właśnie po powrocie z Chin rozpoczął się zwrot w twórczości Kobzdeja, choć same rysunki z podróży nie zdradzają jeszcze kierunku zmiany, pozostając realistycznymi, reporterskimi „migawkami”.

Z dziennika Sokorskiego wiadomo, że grupa przybyła do Pekinu 23 września 1953 roku. Jednym z punktów zwiedzania miasta była wystawa malarstwa Qi Baishi - artysty nieuniknionego w ówczesnych itinerariach - którego konwencja nieco zaszokowała europejskich miłośników realizmu. Ta i inne mimochodem odnotowane reakcje zdradzają, jak skromną wiedzą o kulturze chińskiej dysponowali ówcześni polscy artyści i intelektualiści. W kilka dni później Kobzdej miał oświadczyć, że będzie odtąd malował tylko chińskim pędzlem i tuszem i jak wynika z jego prac, postanowienia tego dotrzymał. Z wystawy poświęconej historii malarstwa chińskiego powrócił z przekonaniem, że zasługą Qi Baishi było zerwanie z „nierealistyczną” konwencją Chin cesarskich i powrót do natury. Wypowiedź ta świadczy zarówno o nieznajomości kontekstu twórczości mistrza, jak i o poczuciu zagubienia wobec tego malarstwa, o próbie jego klasyfikacji w obrębie sprawdzonych wzorców realizmu.

Wizyta w operze w Tianjinie ponownie wystawiła na próbę estetyczną wrażliwość cudzoziemców. Sokorski zadał sobie i towarzyszom pytanie, co właściwie jest realizmem w tym kraju - autentycznie brzmi tu ton niepewności i estetyczno-ideowego zagubienia w obliczu obcej tradycji. Kobzdej zareagował na to, według ministra, przypływem niezadowolenia, wyraźnie broniąc się przed wpływem tej obcości.

W Nankinie padają kolejne wypowiedzi Kobzdeja, uważającego, że sztuka powinna raczej ukazywać idee w konfrontacji z rzeczywistością, niż notować czyste wrażenia. Ale jednocześnie to drugie właśnie czynił w podróży. Sokorski pisał o rikszarzach, że „wyglądają jak chochoły Wyspiańskiego (...), szkoda, że nikt z nas nie może poza Kobzdejem uwiecznić ich w swoim notesie"13. W Szanghaju zaś artysta pracował „z diabelską furią. Chiny rosną w nim w realną prawdę życia, pracy i twarzy ludzkich. (...) Port i życie dżonek, wdzięk i uroda kobiet szanghajskich"14.

\footnotetext{
12 SoKorski 1954. Dalsze informacje o przebiegu podróży i zachowaniach Aleksandra Kobzdeja pochodzą z tej relacji.

13 Ibidem, s. 96.

$14 \quad$ Ibidem, s. 116-117.
} 
Tu także, w Związku Plastyków, przedstawił referat o sztuce. Na podstawie tekstu Sokorskiego można odtworzyć główne wątki tego wystąpienia: tradycja i nowoczesność, relacje pomiędzy treścią i formą, konwencja realistyczna a narodowa, problem bohatera nowej sztuki.

W Hangzhou, które rok wcześniej tak urzekło Kulisiewicza, Kobzdej był w złym humorze. Sokorski notował jego ponure uwagi:

Handżou (...) jest za piękne. (...) Drugi dzień już zastanawiam się, dlaczego właśnie tutaj nie mogę malować. Niebo, jezioro, deszcz - jezioro, niebo, słońce - to za mało, żeby odgadnąć w tym pięknie siebie. (...) Brakuje mi kontrastu brzydoty, konfliktu człowieka ${ }^{15}$.

Odzyskał chęć do pracy w Kantonie, rysując dżonki na Rzece Perłowej - gdzie krople deszczu moczyły mu papier - tworząc niespodziewany i niepożądany bynajmniej „impresjonistyczny” efekt, a także mnicha i piękne dziewczyny. Tam również miał sen o Wietnamie; śniła mu się palmowa strzecha, księżyc, muzyka harfy i śpiew kobiety, odgłos lecącego samolotu. Właśnie sen zainspirował tego wyznawcę realizmu i materializmu do udania się w dalszą podróż, która okazała się wielkim przeżyciem i artystycznym sukcesem.

Po zwiedzeniu wystawy sztuki współczesnej w Hankou ponownie wywiązała się pomiędzy Kobzdejem a Sokorskim dyskusja o różnych pojęciach realizmu; zaczyna dochodzić do głosu poczucie nowego otwarcia, istotnego odkrycia: „Paradoksalny proces wyzwalania własnej osobowości w zetknięciu z inną konwencją oraz inną sztuką" ${ }^{16}$. Pierwszym podsumowaniem artystycznej podróży była wystawa rysunków Kobzdeja otwarta w Akademii Sztuk Pięknych w Pekinie 20 listopada 1953 roku, w obecności licznych artystów i studentów wychwalających „prawdę” jego sztuki, rozumianą w kategoriach socjalistycznego realizmu.

Wkrótce potem Aleksander Kobzdej, Wojciech Żukrowski oraz czeski dziennikarz Karel Prašek wyruszyli do Wietnamu. Prace tam wykonane znalazły szeroki oddźwięk, po powrocie do Polski były wystawiane, publikowane i komentowane. Chiny znalazły się wyraźnie w cieniu tej części wyprawy, z której zachował się też dziennik artysty ${ }^{17}$, a która budziła duże zainteresowanie $\mathrm{z}$ racji aktualnego kontekstu politycznego i niedostępności pogrążonego w wojnie kraju. Rysunki z Wietnamu reprezentowały Polskę na Biennale Weneckim, a w 1955 roku ukazał się luksusowy album z towarzyszącymi im tekstami Żukrowskiego ${ }^{18}$. 
Po krótkim okresie zainteresowania i intensywnej promocji rysunki azjatyckie Kobzdeja popadły w zapomnienie; rychła, radykalna przemiana w twórczości, jego zwrot ku abstrakcji znacznie mocniej przykuły uwagę krytyków i publiczności w poodwilżowej Polsce. Prace bywały incydentalnie prezentowane jako jeden z elementów dorobku artysty, pojawiły się m.in. na wystawie w 20. rocznicę jego śmierci w 1992 roku $^{19}$. Po niej właśnie Muzeum Azji i Pacyfiku nabyło od rodziny zespół 107 prac azjatyckich, w tym 38 z Chin (trzy z nich to dawne ilustracje do książki Sokorskiego). Część z nich pojawiła się w następnym roku na wystawie „Kobzdej - Kulisiewicz - Strumiłło. Rysunki z Azji”, której komisarzem była Barbara Pokorska ${ }^{20}$, a która była następnie wielokrotnie prezentowana za granicą.

Jakkolwiek na bieżąco sam Aleksander Kobzdej wydawał się traktować Wietnam jako istotniejszy, bardziej angażujący etap azjatyckiej podróży, po kilku latach wspomnienia chińskie wciąż dawały o sobie znać. Według krytyków to właśnie „podróż na Wschód” przyczyniła się do zasadniczych przemian w jego twórczości. Według Juliusza Starzyńskiego:

Bezpośrednie zetknięcie z tradycją syntezy wizualnej w sztuce Dalekiego Wschodu, z tą tradycją znaku plastycznego, której sztuka nowoczesna tak wiele zawdzięcza - pozwoliło Kobzdejowi zrewidować nadmierną dosłowność środków wyrazowych realizmu socjalistycznego. Kobzdej znalazł się na drodze, która doprowadziła go w ciągu paru lat do nowych rozwiązań formalnych ${ }^{21}$.

Nie od razu zmiana dała się zauważyć w pracy Kobzdeja, jednak on sam potwierdzał przełomowe znaczenie doświadczenia azjatyckiego i związanych z nim przemyśleń. W rozmowie ze Zbigniewem Herbertem pytał:

Zna pan z widzenia alfabet chiński? No więc niech pan sobie teraz wyobrazi pałac cesarza, którego ściany wypełniają te groźne i wspaniałe znaki... Nawet dla tego, kto nie potrafi ich odczytać, zawierają one potężny ladunek emocji. Jest w tym ogromny rozmach, coś jak komety szastające się po niebie, a także liturgiczny gest kapłana... Zacząłem naśladować ten gest...22

W 1957 roku powstała seria prac inspirowanych chińską kaligrafią - abstrakcyjnych, dynamicznych kompozycji w czerni i bieli. Rozpoczął się nowy rozdział w twórczości Aleksandra Kobzdeja. Nie sposób dziś jednak oprzeć się refleksji, że była to nadal inspiracja światem niezrozumiałym, jak niezrozumiałe pozostało dla artysty chińskie pismo.

\footnotetext{
PŁUCIENNik/Gola 1992.

20 Pokorska/Wasilewska 1993.

21 StARZYŃSKi 1973, s. 102-103.

22 Wg: Deptula 2003.
} 


\section{Strumiłło}

Podróż Andrzeja Strumiłły (1928-2020) różni się od poprzednich, pomimo że odbyła się zaraz po nich, zaledwie w roku 1954, miała podobny plan - rozszerzony o wycieczkę na dalekie Południe, do Yunnanu ${ }^{23}$ - i również trwała około dwóch miesięcy. Artysta miał tylko 26 lat, był młodszy od obu poprzedników, stojący jeszcze na początku artystycznej drogi, gotowy na poszukiwania, otwarty na inspiracje i zmiany. Pierwsza podróż poza Europę, pierwszy kontakt z kulturą inną niż zachodnia przyniosły mu bardzo głębokie doświadczenia i trwałą fascynację.

W trakcie dwóch miesięcy powstało około 200 rysunków, w których widoczne są pierwsze - na ogół jeszcze skromne - próby wprowadzenia nowych wartości formalnych do realistycznego warsztatu. Jak wspominał sam artysta, podróżował z „oczami szeroko otwartymi”, używając chińskiego pędzla, papieru i tuszu²4. Oprócz realistycznych rysunków, zwłaszcza portretowych (porównywalnych do prac Kobzdeja), pojawiają się motywy inspirowane przez chińskie malarstwo i kaligrafię. W niektórych pejzażach tusz rozpływa się miękko w mokrym papierze, niczym w pracach twórców malarstwa „bezkostnego”. Czasem pojawia się wyrazisty kontrast pomiędzy starannie wypracowanym motywem a pustym, białym tłem - rozwiązanie, które w przyszłości stanie się jednym ze znaków firmowych Strumiłły. Korzenie tego rozwiązania również tkwią w chińskim malarstwie, podobnie jak dążenie do syntetycznego ujęcia formy prostym i trafnym gestem. Krystalizuje się powoli skłonność artysty do detalu studiowanego niemal jak forma abstrakcyjna, w głębokim skupieniu uwagi, towarzysząca mu następnie przez całe twórcze życie. Już w 1954 roku można ją zauważyć w wizerunkach kobiet z Kunmingu w ludowych strojach; w kolejnej podróży chińskiej z 1961 roku, bardziej dojrzałej i skłonnej do eksperymentu, owe studia detali przybiorą formy bliskie abstrakcji.

Dziennik z 1954 roku $^{25}$ zawiera głównie rzeczowe zapiski, dotyczące odwiedzanych miejsc i spotykanych osób, a także wyznania tęsknoty za krajem. Rzadko pojawia się obrazowe zdanie, takie jak to z 18 października: „Pola ryżowe błyszczą jak srebrne lustra we mgle”. Interesująca notatka z Kunmingu mówi, po stosunkowo obszernym zapisie zachwytów nad malowniczością „typów” miejscowej ludności: „Zamawiam modele na jutro do hotelu”. Niewątpliwie rzuca to światło na kontekst powstawania wizerunków osób z mniejszości etnicznych. W Chinach grupy te jeszcze za czasów cesarstwa podlegały wewnętrznej egzotyzacji, a już w początkach Chińskiej Republiki Ludowej były prezentowane cudzoziemcom jako

\footnotetext{
${ }^{23} \mathrm{~W}$ archiwum artysty zachowało się jego zdjęcie na tle klasztoru w Yunnanie, wtopionego w mglisty pejzaż; STRUMiŁŁo 1997, s. 80.

24 PoKorska/WASILEWSKa 1993, s. 27.

25 W archiwum autora, uprzejmie udostępniony przez niego do digitalizacji w Archiwum Materiałów Wizualnych Muzeum Azji i Pacyfiku.
} 
atrakcja turystyczna, żywa tradycja kontrastująca z modernizacją wielkich ośrodków miejsko-przemysłowych.

W notesie są też bardzo szkicowe rysunki, właściwie szybkie notatki do rysunków „właściwych” - artysta często zapisuje, że planuje narysować konkretny temat. Wyróżnia się wśród nich cykl łodzi żaglowych z Szanghaju o świetnie uchwyconej $\mathrm{w}$ syntetycznych liniach formie.

W odróżnieniu od Kulisiewicza i Kobzdeja Strumiłło, artysta niezwykle wszechstronny, obszernie komentował swoją twórczość plastyczną w literackiej formie. W jego tekstach, stanowiących zarazem formę wspomnień i refleksji artystyczno-filozoficznej, podróż z 1954 roku zajmuje zawsze istotne miejsce:

Był to rok 1954. Na doświadczenia awangardy Strzemińskiego nakładały się tysiącletnie warstwy rozcieranego na kamieniu tuszu. Sędziwy Qi Baishi uniósł rękę na moje powitanie ${ }^{26}$.

Oglądałem żywe twarze i jesienne krajobrazy, zwiedzałem muzea i zabytki, ściskałem dłonie przodowników pracy i ministrów, a stojący na progu swego domu i grobu Ci Bai Szi żegnał mnie uniesieniem dłoni. Z perspektywy lat czterdziestu ostro widzę wagę tej przygody ${ }^{27}$.

Blisko 200 rysunków z Państwa Środka stanowi moment istotny w mojej edukacji artystycznej. Silny wpływ starej kultury, znaku i hieroglifu, klasycznego warsztatu, doskonałości papieru, tuszu i pędzli, wyrafinowana kuchnia, kontakt osobisty z wybitnymi twórcami, jak niezapomniany Qi Baishi, nie pozostały bez wpływu na moją manierę $e^{28}$.

Spotkanie z Qi Baishi to dla Andrzeja Strumiły moment konstytutywny $\mathrm{w}$ życiu, nie tylko artystycznym. Wizyta w pracowni wiekowego malarza stanowiła nieodzowny punkt programu zagranicznych delegacji kulturalnych; trudno się oprzeć wrażeniu, że musiało to być nieco męczące dla dziewięćdziesięcioletniego już wtedy człowieka. Dla młodzieńca z Polski jednak przeżycie było potężne, formacyjne, wielokrotnie później przywoływane. Namalowany w jego obecności obraz Świeży aromat i bogate barwy - typowe dla późnej twórczości Qi Baishi przedstawienie kwitnącej gałęzi brzoskwini - podarował Strumiłło w 1978 roku do zbiorów młodego Muzeum Azji i Pacyfiku, wraz z dokumentacją fotograficzną starego mistrza przy pracy ${ }^{29}$. Warto tu jednak zauważyć, że we wspomnianym dzienniku

\footnotetext{
26 Strumileo 1997, s. 7.

27 POKORSKa/WASILEWSKa 1993, s. 27.

28 STRUMiŁŁo 2011, s. 223.

29 W zbiorach Muzeum znajduje się także około 400 prac autorskich Andrzeja Strumiłly z różnego czasu, w większości rysunków z podróży, a także projekty ilustracji książkowych, plakaty i medale oraz zgromadzone przez artystę kolekcje obiektów azjatyckich.
} 
wydarzenie to jest opisane podobnie jak inne spotkania, treściwie i powściągliwie; w późniejszych relacjach nabiera dodatkowych wymiarów.

Chińskie oczarowanie stało się pierwszym krokiem, początkiem wielkiej podróży azjatyckiej trwającej przez kilka kolejnych dekad. Andrzej Strumiłło odwiedził Indie, Nepal, Wietnam, rosyjski Daleki Wschód i Syberię, Mongolię, Tajlandię, Japonię, Syrię, Turcję, Kaukaz. Podróże te, wyjątkowe w przypadku artysty polskiego tego pokolenia, składają się na prawdziwy Grand Tour artysty Zachodu, głęboko zafascynowanego Wschodem. Ślad azjatycki przewijał się przez wszelkie formy jego twórczości: rysunki wykonywane bezpośrednio w podróży, fotografie, obrazy, plakaty, projekty wystaw i książek, ilustracje, poezje, a nawet tworzone kolekcje - nie tylko dla siebie, ale również dla Muzeum Azji i Pacyfiku w Warszawie oraz Muzeum Etnograficznego w Krakowie. Jego twórczość, szeroko obecna w przestrzeni intelektualnej Polski lat 60., 70. i 80., miała znaczący wpływ na ówczesną ikonosferę i wyobraźnię. W licznych tekstach o sztuce i tradycjach Azji, publikowanych m.in. w „Projekcie”, „Kontynentach” czy popularnym, a zarazem ambitnym „Ty i Ja”, we wstępach do katalogów wystaw, przekazywał czytelnikom swoją rozległą wiedzę, przefiltrowaną przez osobiste doświadczenie, gust, refleksję. Przypisywał „Azji”, traktowanej jak pewna kulturowa, a nawet mistyczna całość inspirację nie tylko artystyczną, ale i duchową: „Z czasem, a były to dziesięciolecia, zdałem sobie sprawę, że Azja uczyniła mnie innym człowiekiem. Duch Azji wzniósł we mnie małą stupę Ciszy i Zgody, a także suburgan Wiecznego Wiatru"30.

Owa zmitologizowana Azja staje się z czasem dla Strumiłły, jak dla wielu artystów świata euroatlantyckiego, ojczyzną odchodzących w przeszłość wartości: tradycji, uważności, twórczej dyscypliny. To w niej łatwiej dostrzec nierozerwalną więź tego, co widzialne i niewidzialne, świata rzeczy i świata myśli; to na Wschodzie kształtuje się poczucie jedności rzeczywistości i jednocześnie umiejętność skupienia się na jej najdrobniejszym elemencie.

W czasach wielkich technologii i działań multimedialnych w sztukach świadomie sięgamy po pióro lub pędzel umoczone w tuszu. Czerń na bieli. Żyjąca czerń i żyjąca biel. Czerń, która może stać się wszystkim i biel, która wszystko przyjąć może. Tak jak noc i dzień, jak zło i dobro, jak śmierć i życie, jak yang i yin ${ }^{31}$.

Ogromny kontynent, choć dobrze znany Andrzejowi Strumille z licznych i bynajmniej nie powierzchownych podróży, uległ w jego wyobraźni idealizacji i swego rodzaju homogenizacji. W poszukiwaniu artystycznej i życiowej prawdy pozostał on człowiekiem Zachodu na Wschodzie odchodzącym w przeszłość - a może nigdy nieistniejącym w upragnionej postaci. A jednak w kolejnych podróżach ani na

$30 \quad$ Ibidem, s. 7.

31 Ibidem. 
chwilę nie stracił ostrości widzenia konkretu, a jego rysunki realizują wyznaczony sobie ideał równowagi pomiędzy detalem i syntezą. Jak pisała w 2007 roku Danuta Wróblewska: „Rysunek wszedł mu w nawyk - zwykły i jednocześnie ponadczasowy dokument widzianego. Także jako sposób na analizę rzeczy"32. Niewątpliwie było to również konsekwencją pierwszej chińskiej podróży.

Zapis plastyczny i literacki tych trzech podróży zwraca uwagę na interesujące aspekty życia artystycznego początku lat 50., silnie uwikłanego w tło polityczne i retorykę komunistycznego internacjonalizmu. Ukazuje moment nowego, specyficznego w tym kontekście otwarcia polskiej sztuki na świat pozaeuropejski oraz tego otwarcia skutki - na ogół wykraczające poza oficjalnie formułowane oczekiwania samych artystów i autorów polityki kulturalnej. Dokumentacja indywidualnych doświadczeń poszczególnych twórców wpisuje się więc w szerszy obraz „socjalistycznego postkolonializmu", o którym pisze ostatnio Adam F. Kola ${ }^{33}$, otwierając bardzo obiecujący obszar analiz.

\section{Bibliografia}

DeptuŁa 2003 - Bogusław Deptuła, W szczelinie. Niedocenione malarstwo Aleksandra Kobzdeja (1920-1972), „Tygodnik Powszechny”, nr 6 (2796), 9 lutego 2003.

Hu GuAng Hua 2011 - Hu Guang Hua, Investigation of Art Exchanges between China and Poland in the 1950s, [w:] Poland - China. Art and Cultural Heritage, red. Joanna Wasilewska, Kraków 2011, s. 211-215.

JАСОВу 2009 - Marcin Jacoby, Zarys historii wymiany kulturalnej pomiędzy Polska a Chinami w latach 1949-2009, [w:] Polska - Chiny. Wczoraj, dziś, jutro, red. Bogdan Góralczyk, Toruń 2009, s. 331-367.

JAKIMOWICZ 1976 - Irena Jakimowicz, Tadeusz Kulisiewicz, Warszawa-Berlin-Budapeszt 1976.

Kola 2018 - Adam F. Kola, Socjalistyczny postkolonializm: rekonsolidacja pamięci, Toruń 2018.

Li CHaO - Li Chao, Dissemination of Polish Fine Arts in China in the 1950s, [w:] Poland - China. Art and Cultural Heritage, red. Joanna Wasilewska, Kraków 2011, s. 217-221.

Osı́́sKi 2008 - Zbigniew Osiński, Polskie kontakty teatralne z Orientem wXX wieku, cz. 1-2, Gdańsk 2008.

PejČochovà 2008 - Michaela Pejčochová, The Origins of the $20^{\text {th }}$ Century Chinese Paintings Collection in the National Gallery in Prage, „Orientations”, t. 39, nr 3, April 2008.

PŁuciennik/Gola 1992 - Dorota Płuciennik, Jola Gola, Aleksander Kobzdej 1920-1972, Warszawa 1992.

Pokorska/Wasilewska 1993 - Barbara Pokorska, Joanna Wasilewska, Kobzdej, Kulisiewicz, Strumiłto. Rysunki z Azji, Warszawa 1993.

\footnotetext{
32 Za: StrumiŁeo 2011, s. 463.

33 Kola 2018.
} 


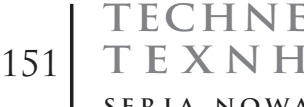

SKrodZKi 1979 - Wojciech Skrodzki, Tadeusz Kulisiewicz - moje spotkania, Warszawa 1979.

SOKORSKI 1954 - Włodzimierz Sokorski, Dziennik podróży. Dwa miesiące w Chinach, Warszawa 1954.

STARZYŃSKi 1973 - Juliusz Starzyński, Polska droga do samodzielności w sztuce, Warszawa 1973.

STrumiŁŁo 1997 - Andrzej Strumiłło, Azja, Warszawa 1997.

STRUMiŁŁo 2011 - Andrzej Strumiłło, Summa, Suwałki 2011.

Szelegejd 1984 - Jacek Szelegejd, Azja Mistrza Kulisa. Rysunki Tadeusza Kulisiewicza z Chin i Indii, Warszawa 1984.

WASILEWSKA 2009 - Joanna Wasilewska, Aleksander Kobzdej w Chinach - spojrzenie polskiego artysty w latach pięćdziesiątych XX w., [w:] Sztuka Chin, red. Joanna Wasilewska, Warszawa 2009.

Żukrowski 1954 - Wojciech Żukrowski, Chiny i Wietnam w rysunkach Aleksandra Kobzdeja, Warszawa 1954 


\section{Three Polish artists in China in the 1950s}

$\ln$ the 1950s, delegations of Polish artists to China were an important element of the newly formed Eastern Bloc's cultural politics. In the assumption they were means of establishing ideological similarities of art in socialist countries and strengthening political bonds. In practice, it was often a significant artistic experience and a source of inspiration for its participants. The article analyzes three cases of artists whose drawings documenting similar journeys are currently in the collections of the Asia-Pacific Museum in Warsaw, and in whose work this experience was marked in different ways. For Tadeusz Kulisiewicz, the Chinese journey was an episode, which he returned to after many years. The experience inspired Aleksander Kobzdeja to make fundamental changes in his art, beginning a process that from socialist realism had lead him to abstraction. In the case of Andrzej Strumiłło, it was a start of an exquisite, artistic path, largely marked by the fascination with cultures and arts of Asian countries.

Keywords: Polish Art, Polish Artists in China, social realism, Polish modern art, China. 